\title{
Sighting of the fin whale in the Eastern Subtropical South Pacific: Potential breeding ground?
}

\author{
Avistamiento de la ballena común en el Pacífico Sur Oriental Subtropical: \\ ¿Una potencial área de reproducción?
}

\section{Jorge Acevedo', Magnus O’Grady² and Ben Wallis ${ }^{3}$}

\author{
${ }^{1}$ Centro de Estudios del Cuaternario Fuego-Patagonia y Antártica, Fundación CEQUA, 21 de Mayo 1690, Punta Arenas, \\ Chile.jorge.acevedo@cequa.cl \\ ${ }^{2} 10$ Ebor st., Te Aro, Wellington, New Zealand \\ ${ }^{3} 6-6$ Ormond Street, Bondi Beach, NSW 2026, Australia
}

\begin{abstract}
Here we report a sighting of a large school of fin whales on 30th May 2010 approximately 2,810 km west of the continental coast of Chile $\left(21^{\circ} 27^{\prime} \mathrm{S}, 97^{\circ} 34^{\prime} \mathrm{W}\right)$. This sighting supports the limited available information that fin whales migrate to Sub-tropical open ocean waters during the austral autumn-winter. Given the accepted migration pattern of fin whales, reproducing at low latitudes from April or May, we suggest that the geographic location of our sighting could correspond to, or be near to, a breeding ground for this species in the South Pacific.
\end{abstract}

Key words: Balaenoptera physalus, South Eastern Pacific, winter distribution, Southern Hemisphere

\section{INTRODUCTION}

The fin whale Balaenoptera physalus (Linnaeus, 1758) is a cosmopolitan species found in most large water masses of the world, from the Equator to the polar regions (Aguilar 2002, Jefferson et al. 2008), although they may be absent near the ice edge (Gambell 1985).

In the Southern Hemisphere, fin whales engage in north-south seasonal migration, feeding in high-latitude areas during the summer (above $50^{\circ} \mathrm{S}$ ) (Brown 1954, 1962, Clarke 1962, Gambell 1974, 1985), and breeding in temperate or tropical waters during the winter (Mackintosh 1942, Gambell 1974, Aguilar 2002). Moreover, the largest concentrations are usually present in temperate and cold waters outside the continental slope (Aguilar 2002). Although the main feeding grounds have been broadly described, the location and season in which breeding and calving occurs remains largely unknown (Mackintosh 1965) because, unlike other mysticetes large cetaceans, calving does not appear to take place in distinct inshore areas (Reeves et al. 2002, Jefferson et al. 2008).

In the low latitudes off Chilean waters, fin whale sightings are almost always reported at more than $60 \mathrm{~km}$ off the coast, and they are usually found alone or in small groups throughout the year (Clarke 1962, Aguayo et al. 1998) (Fig. 1). Feeding behavior has recently been recorded in the water of the 'Reserva Nacional Pingüino de Humboldt' (2909’S), during the austral summer with group sizes ranged from a single individual to small groups (Capella et al. 1999, Perez et al. 2006). To our knowledge, the only record of a large number of fin whales off the north-central Chilean coast was reported by Clarke (1962), at a considerable distance from the coast and in a locality almost entirely unexplored by whale catchers. Here we report a sighting of a large school of fin whales in the Eastern Subtropical South Pacific Ocean and discuss the possibility that this area may represent a breeding area for fin whales, or alternatively, that the groups constituted breeding individuals.

\section{Materials And Methods}

This sighting was recorded by crew members aboard the yacht 'Balaena', which was sailing from Chile to the Gambier Islands, French Polynesia Archipelago in May 2010. Non scientific crew were aboard the yacht, therefore this report is based on the logbook annotations and photographs of the skipper Magnus O’Grady. The species identification was made by the first author based on the review on several photos provided by the skipper in 2011.

\section{Results ANd Discussion}

The sighting was made at $21^{\circ} 27^{\prime} \mathrm{S}, 97^{\circ} 34^{\prime} \mathrm{W}$ [1,517 nautical miles (nm) of continental coast of Chile or $728 \mathrm{~nm}$ to northeast of Easter Island] on the $30^{\text {th }}$ May 2010. Weather 


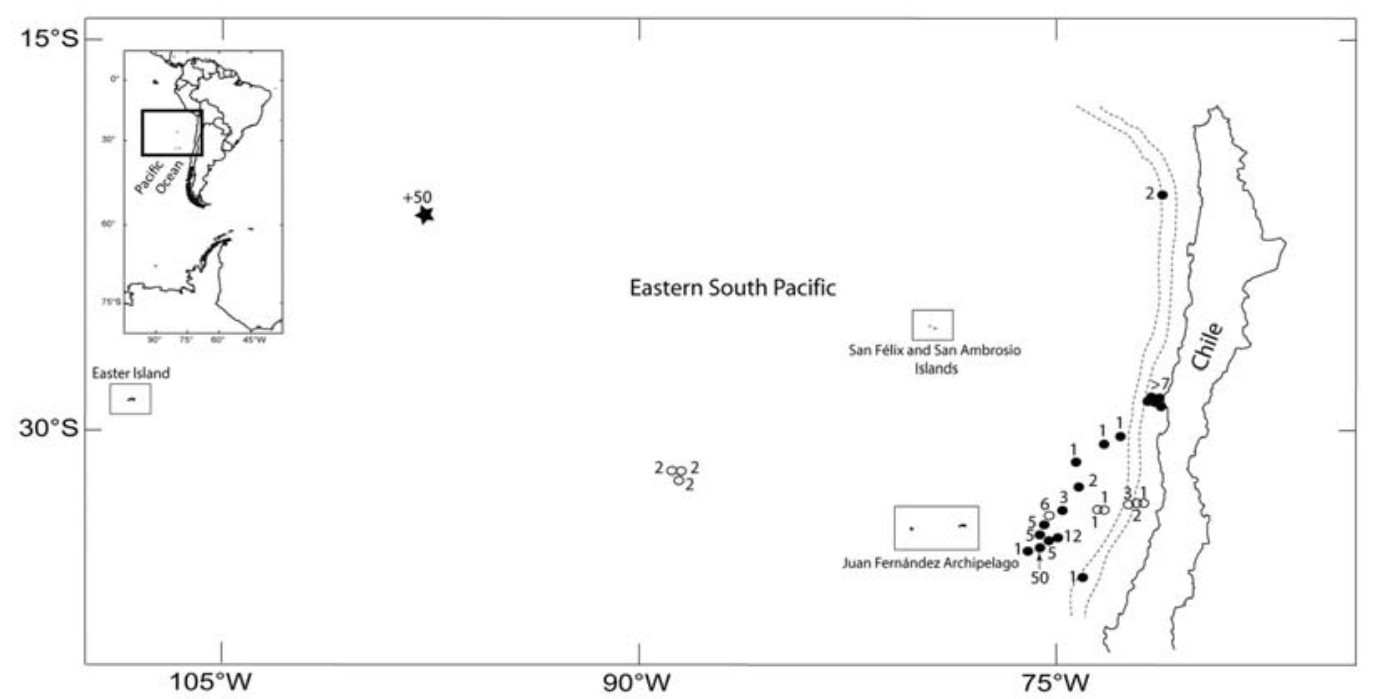

\begin{abstract}
Figure 1. Sighting location of a large group of fin whales on 30 May, 2010 (star) relative to previously recorded sightings off north-central Chilean waters (circles). Previous austral winter sightings are indicated as open circles. Dotted lines show the continental slope. The numbers at each sighting represents group size / Localización del gran grupo de ballenas de aleta avistada el 30 de mayo 2010 (estrella) en relación a los avistamientos previamente documentados en aguas del norte de Chile (círculos). Previos avistamientos invernales son indicados en círculo abierto. La línea punteada muestra el talud continental y el número sobre cada avistamiento representa el tamaño de grupo de ballenas
\end{abstract}

conditions at the time of the sighting were optimal with a swell of 1-1.5 m and a wind speed of $20 \mathrm{kn}$ (knots) from the southeast. The first whales were sighted around 10:00 $\mathrm{h}$ and thereafter more whales continued to approach from astern in groups of 2-3. All whales approached from the same direction, heading west. Whales continued to pass the boat until late afternoon, around 5-6 h after the first sighting. An hour after the last whale was sighted, another small group of whales (near 10 individuals) also passed within a close distance of the yacht headed in westerly direction.

The swimming speed of the whales was high but seemed to slow as they approached the yacht. While near the vessel, the whales swam near the surface on a very similar course to that of the yacht, at an estimated 8 kn. No prolonged diving was observed and many whales broke the surface with their heads and/or rolled on their backs and waved their pectoral fins in the air. Several animals were inquisitive swimming very close along side, astern and under the boat.

All the animals were identified as fin whales by the presence of asymmetrical body pigmentation, with white lower and upper lips on the right side of the head, while the left side lips were largely dark, by a lightgray V-shaped 'chevron' (pointing forward) on the back behind the head, and a dorsal fin that rises at a shallow angle from the animal's back (Fig. 2). No other species were sighted or photographed passing the yacht in close proximity.

It was estimated that the groups passing the yacht numbered well over 50 individuals, and may have numbered more than 100. Based on sightings and photographs, no cow-calf pairs were seen. Other groups of baleen whales were sighted in the area swimming in the same direction as the group of fin whales but because they didn't approach the yacht, the species could not be confirmed.

The geographical range of fin whales is similar to that of other whales such as the blue whale, and although the primary feeding grounds of fin whales are generally known (e.g., Gunther 1953, Mackintosh \& Brown 1956, Clarke 1962, Mackintosh 1965, 1966), there remains considerable uncertainty in the location of breeding areas and migration routes. In the Southern hemisphere, it is generally thought that fin whales migrate from southern feeding areas to the north during the austral winter into warmer waters to breed (Risting 1928, Mackintosh \& Wheeler 1929, Aguilar 2002, Jefferson et al. 2008). However, historical catch data suggests that not all members of the population migrate to low latitudes (Mitchell 1974). 

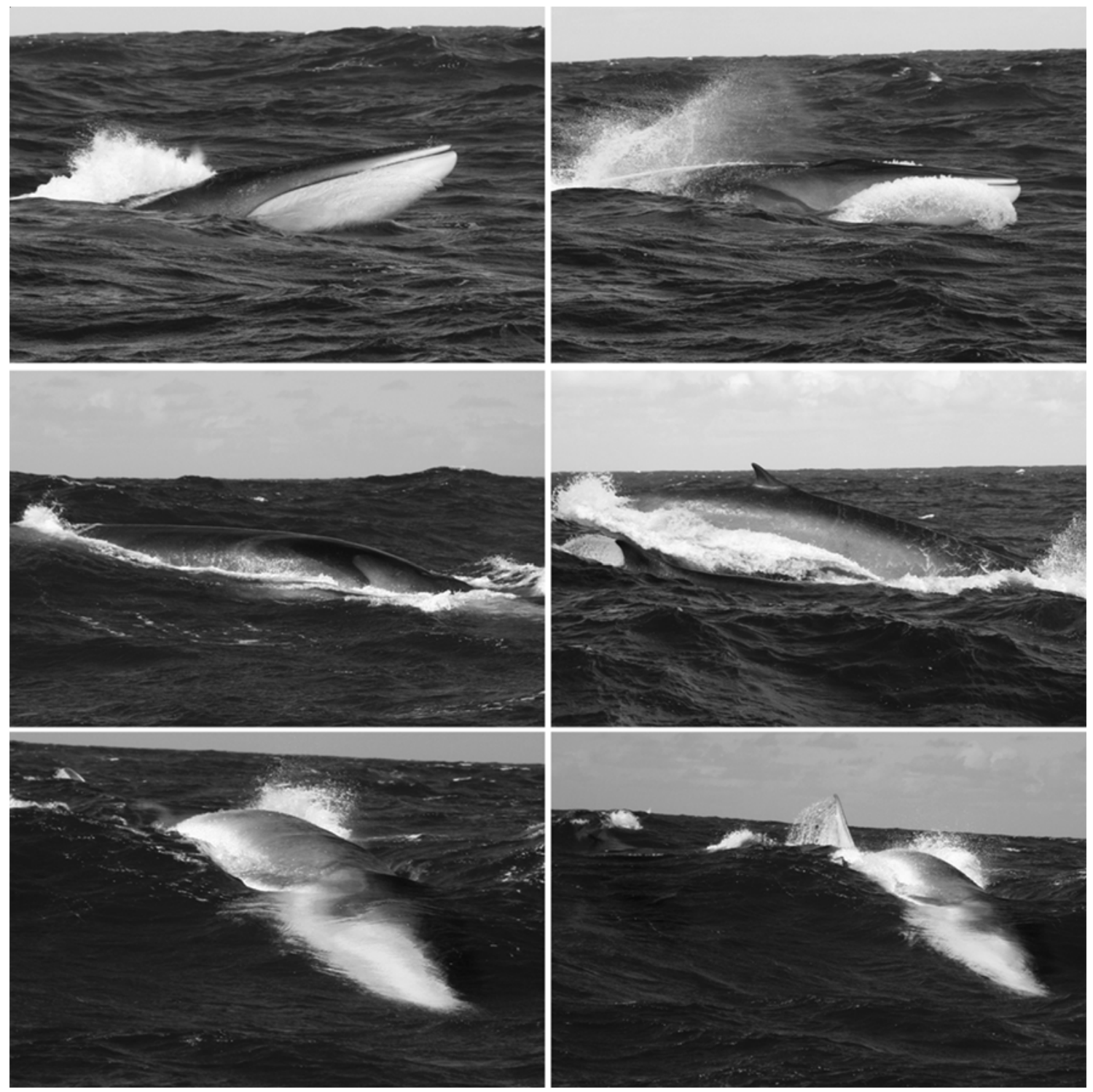

Figure 2. Photographs of fin whales sighted at $21^{\circ} \mathbf{2 7}$ 'S, Chile, on 30 May 2010. Photographs by Magnus O'Grady / Fotografías de las ballenas de aleta avistadas en los $21^{\circ} 27^{\prime} \mathrm{S}$, Chile, el 30 de mayo 2010 . Fotografías de Magnus O'Grady

Data identifying breeding habitats is mostly lacking. Unlike other species such as humpback whales, fin whales do not appear to concentrate in coastal regions during the winter to breed. Also, it does not appear that they are ever seen in large numbers in warmer waters during winter, in contrast to the summer months when large groups are seen feeding in cold waters (Mackintosh 1942). In fact, Harmer (1928) suggests that fin whales generally disperse to deep waters during the winter perhaps spanning from tropical to sub-Antarctic waters.
To our knowledge, only a few sightings of large groups of fin whales have occurred during the winter in the South Atlantic and Pacific Ocean. Wheeler (1946) recorded forty fin whales in central South Atlantic waters between about $24^{\circ}$ and $7^{\circ} \mathrm{W}$ (over 900 miles or more from any continental coast) along the latitude $20^{\circ} \mathrm{S}$ in six days from August 21st 1943, and Clarke (1962) recorded 84 fin whales, including one concentration of 50 and another of 12 about 150 to $180 \mathrm{~nm}$ from the shore (beyond the range of Chilean whaling land stations) and mostly between $32^{\circ}$ to $34^{\circ} \mathrm{S}$, 
on a cruise off the coast of Chile in October and November 1958. However, this sighting occurred at a time when fin whales were likely to be on their southward migration. Aguayo-Lobo et al. (1998) reported nine groups of fin whales between $73^{\circ} 42^{\prime} \mathrm{W}$ and $88^{\circ} 49^{\prime} \mathrm{W}$ along the latitude $33^{\circ} \mathrm{S}$ during five winter cruises from Valparaíso to Easter Island, and in spite of most of the groups being seen beyond the continental shelf, the group size did not exceed 6 individuals (Fig. 1). Although no feeding and/or breeding behavior was directly observed, the large number of rorquals and geographic location in deep water far off the continental coast would be within the expected geographical range of this species during the austral autumn-winter season.

Our sighting occurred during late May, consistent with a timing of migration to the breeding areas. Therefore, it could represent potential reproductive groups, either present in or headed toward a breeding area. Although no breeding behavior was annotated in the logbook and no calves were observed in photographs, this information is consistent with the knowledge provided by whalers that this school of fin whales may have been breeding. For example, the analyses of the fetuses from the logbooks made by whalers suggest that the maximum time of pairing for fin whales occurs around July, with conception peaking in July and August (Hinton 1925, Harmer 1928). Risting (1928) also used data supplied by various whaling companies and concluded that breeding of fin whales occurs from June to September.

However, Mackintosh \& Wheeler (1929) question the accuracy of these reports due to uncertainty in the growth rate during the early stages of gestation, and state that confirmation of these data is required, based on observations of the ovaries and testes of adults. Their study, based on the occurrence of fetuses and the correlation of the seasonal movements and other habits of the whales with the reproductive process, suggests that the breeding season of southern hemisphere fin whales begins in the earlier part of the austral winter, in April or May, with the height of the pairing season occurring towards the end of June and calves mostly being born in June and July. This timing was also confirmed by Laws $(1959,1961)$ who analyzed 956 fetuses and found that $77 \%$ of fetuses were conceived from April to August.

We therefore suggest that the geographic location of our sighting could correspond to, or be near, a breeding ground for this species in the South Pacific. As our assumptions are based on a single sighting and the knowledge of breeding habits and reproductive processes is scarce, further research is needed to support our hypothesis. To address this question, we recommend conduct further pelagic survey and examination of skipper's logbooks, as well as satellite tagging studies, given that, at least in winter, fin whales are widely dispersed over an immense area in the open ocean of subtropical waters.

\section{AcKNOWLedgments}

We thank the Director of the Fundación CEQUA for the constant support in Marine Mammals surveys, as well as to Prof. Anelio Aguayo-Lobo for provide valuable assistance with several old whaler's papers. We thank also to Dr. Luis Pastene, Dr. Scott Gende and anonymous referee's for improve this note. This is contribution No. 43 of the Marine Mammal Research Program, Fundación CEQUA.

\section{LITERATURE CITED}

Aguayo-Lobo A, R Bernal, C Olavarría, V Vallejos \& R Hucke-Gaete. 1998. Observaciones de cetáceos realizadas entre Valparaíso e Isla de Pascua, Chile, durante los inviernos de 1993, 1994 y 1995. Revista de Biología Marina y Oceanografía 33: 101-123.

Aguilar A. 2002. Fin whale, Balaenoptera physalus. In: Perrin WF, BJ Würsig \& JGM Thewissen (eds). Encyclopedia of marine mammals, pp. 435-438. Academic Press, San Diego.

Brown SG. 1954. Dispersal in blue and fin whales. Discovery Report 26: 355-384.

Brown SG. 1956. Whale marks recently recovered. Norsk Hvalfangsttid 45: 661-664.

Brown SG. 1962. A note on migration in fin whales. Norsk Hvalfangsttide 51: 13-16.

Capella J, Y Vilina \& J Gibbons. 1999. Observación de cetáceos en isla Chañaral y nuevos registros para el área de la Reserva Nacional Pingüino de Humboldt, norte de Chile. Estudios Oceanológicos 18: 57-64.

Clarke R. 1962. Whale observation and whale marking off the coast of Chile in 1958 and from Ecuador towards and beyond the Galapagos Islands in 1959. Norsk Hvalfangsttid 51: 265-287.

Gambell R. 1974. The fin and sei whales stocks off Durban. In: Schevill WE (ed). The whale problem. A status report, pp. 82-86. Harvard University Press, Cambridge.

Gambell R. 1985. Fin whale, Balaenoptera physalus (Linnaeus, 1758). In: Ridgway SH \& R Harrison (eds). Handbook of marine mammals 3: 171-192. Academic Press, London. 
Gunther ER. 1953. The habitats of fin whales. Discovery Report 25: 113-142.

Harmer SF. 1928. History of whaling. Proceedings of Linnaeus Society of London 140: 51-95.

Hinton MAC. 1925. Report on the papers left by the late Major Barrett-Hamilton, relating to the whales of South Georgia, pp. 57-209. Crown Agents for the Colonies, London.

Jefferson TA, MW Webber \& RL Pitman. 2008. Marine mammals of the world. A comprehensive guide to their identification, 572 pp. Academic Press, New York.

Laws RM. 1959. The foetal growth rates of whales with special reference to the fin whale, Balaenoptera physalus Linn. Discovery Report 29: 281-308.

Laws RM. 1961. Reproduction, growth and age of southern fin whales. Discovery Report 31: 327-486.

Mackintosh NA. 1942. The southern stocks of whalebone whales. Discovery Report 22: 197-300.

Mackintosh NA. 1965. The stocks of whales, 232 pp. Fishing News (Books), London.

Mackintosh NA. 1966. The distribution of Southern blue and fin whales. In: Norris KS (ed). Whales, dolphins and porpoise, pp. 125-145. University of California Press, San Diego.
Mackintosh NA \& SG Brown. 1956. Preliminary estimates of the Southern populations of the larger baleen whales. Norsk Hvalfangsttid 45: 469-480.

Mackintosh NA \& JFG Wheeler. 1929. Southern blue and fin whales. Discovery Reports 1: 257-540.

Mitchell ED. 1974. Present status of northwest Atlantic fin and other whale stocks. In: Schevill WE (ed). The whale problem. A status report, pp. 108-161. Harvard University Press, Cambridge.

Pérez MJ, F Thomas, F Uribe, M Sepúlveda, M Flores \& R Moraga. 2006. Fin whales (Balaenoptera physalus) feeding on Euphausia mucronata in nearshore waters off NorthCentral Chile. Aquatic Mammals 32: 109-113.

Reeves RR, BS Stewart, PJ Clapham \& JA Powell. 2002. Sea mammals of the world, 572 pp. A\&C Black Publishers Limited, London.

Risting S. 1928. Whales and whale foetuses. Statistics of catch and measurement collected from the Norwegian Whaler's Association, 1922-5. Rapports et Procès-Verbaux des Réunions. Conseil International pour l'Éxploration de la Mer l: 1-122.

Wheeler JFG. 1946. Observations on whales in the South Atlantic Ocean in 1943. Proceeding of Zoological Society of London 116(2): 221-224.

Received 11 May 2012 and accepted 27 August 2012

Associate Editor: Maritza Sepúlveda M. 